\title{
Determinan Metode Pembayaran Akuisisi di Indonesia: Bukti Empiris di Indonesia
}

\author{
Rahmat Setiawan \& Valiant Mahdi Syihaby Nur Hasyim \\ Fakultas Ekonomi dan Bisnis, Universitas Airlangga \\ e-mail: rahmatsetiawan@feb.unair.ac.id \& valiant.mahdi.syihaby-2016@feb.unair.ac.id
}

\begin{abstract}
This research purpose to examine what factor that determine method of payment acquisition in Indonesia. The period of sample during 2000-2017 and using multinomial logistic regression. There are 85 samples of transactions (57 using cash payment, 18 using mix payment, and 10 using stock payment). Independent variables are market to book ratio, market capitalization, tobin's $Q$, cash flow, and standard deviations of return. Acquirer Correlation as a control variable. This study find that market to book ratio has positive effect on stock and mix payment method than cash payment method at 10\%. Tobin's Q has positive effect on mix payment method than cash payment method at $10 \%$.
\end{abstract}

Keywords: acquisition, method of payment acquisitions, market to book ratio, market capitalization, tobin's $Q$, cash flow, standard deviations of return, acquirer correlation

\section{A. PENDAHULUAN}

Akuisisi merupakan langkah yang dilakukan oleh perusahaan untuk memperoleh pertumbuhan perusahaan secara anorganik. Motif utama dilakukannya akuisisi adalah sinergi. Sinergi tersebut diperoleh dari peningkatan pendapatan, cost reduction, tax gains, dan tereduksinya biaya modal. Ketika perusahaan memutuskan untuk melakukan akuisisi, perusahaan harus memikirkan metode pembayaran apa yang akan dipilih karena terkait apakah transaksi yang dilakukan undervalue ataukah overvalue.

Transaksi akuisisi dapat dilakukan dengan tiga metode pembayaran, yaitu kas, saham, dan campuran (kombinasi antara kas dengan saham). Market to book ratio, kapitalisasi pasar, tobin's $Q$, cash flow, dan standard deviasi return saham dapat memengaruhi metode pembayaran akuisisi. Bouwman, et al (2006) mengemukakan hasil penelitiannya bahwa akuisitor akan memilih metode pembayaran akuisitor dengan saham apabila market to book ratio tinggi karena memiliki intangible asset dan peluang pertumbuhan yang lebih besar. Ismail dan Krause (2010), dan Boone, et al (2014), mengungkapkan hasil penelitiannya yang menunjukkan bahwa kapitalisasi pasar akuisitor yang tinggi akan menggunakan metode pembayaran akuisisi dengan kas.

Alshwer et al. (2011) dan Yang et al. (2017) mengungkapkan hasil penelitiannya yang menyatakan bahwa akuisitor yang memiliki nilai Tobin's Q tinggi cenderung untuk tidak memilih metode pembayaran akuisisi dengan kas dan lebih memilih untuk melakukan penghematan kas demi menghindari opportunity cost proyek yang memiliki net present value (NPV) positif di masa datang. Cash flow positif dan signifikan terhadap pilihan metode pembayaran akuisisi dengan kas pada hasil penelitian yang dilakukan oleh Yang et al. (2017). Penelitian yang dilakukan oleh Boone et al. (2014) dan Hasyim (2015) menunjukkan bahwa semakin tinggi standard deviasi return saham, maka akusitor akan memilih metode pembayaran akuisisi dengan saham atau sebagian dengan saham ketika ada ketidakpastian value akuisitor lebih tinggi dan sebaliknya akui- 
sitor yang memiliki standard deviasi rendah akan memilih metode pembayaran akuisisi kas. Korelasi bisnis akuisitor merupakan variabel kontrol pada penelitian ini. Mengidentifikasi faktor-faktor yang memengaruhi metode pembayaran akuisisi di Indonesia periode 2000-2017 sebagai fokus pada penelitian ini.

\section{B. STUDI PUSTAKA DAN UJI HIPOTESIS}

\section{Market to Book Ratio}

Market to book ratio adalah rasio antara market value saham perusahaan dengan book value ekuitas perusahaan. Perusahaan yang dikelola dengan baik dan beroperasi secara efisien dapat memiliki nilai pasar yang lebih tinggi daripada nilai buku asetnya (Sudana, 2011:24). Apabila akuisitor yang memiliki market to book ratio tinggi, maka akan membayarkan biaya akuisisi yang lebih rendah dengan menggunakan saham daripada menggunakan kas. Menghitung market to book ratio dengan persamaan berikut.

Nilai buku ekuitas $=\frac{\text { Total ekuitas }}{\text { Jumlah saham yang beredar }}$

Market to book ratio $=\frac{\text { Closed Price }}{\text { Nilai buku ekuitas }}$

Keterangan:

Total ekuitas $\quad=$ Total ekuitas akuisitor Jumlah saham yang beredar $=$ Jumlah saham

Closed price = Harga pasar per lembar saham akuisitor

Hipotesis dirumuskan sebagai berikut.

H1.1: Semakin tinggi market to book ratio, maka akan semakin tinggi pula probabilitas akuisitor memilih metode pembayaran akuisisi dengan saham dibandingkan metode pembayaran akuisisi dengan kas.

H1.2: Semakin tinggi market to book ratio, maka akan semakin tinggi pula probabilitas akuisitor memilih metode pembayaran akuisisi dengan campuran dibandingkan metode pembayaran akuisisi dengan kas.

\section{Kapitalisasi Pasar}

Kapitalisasi pasar merupakan hasil perkalian antara harga per lembar saham dengan jumlah saham yang beredar. Apabila akuisitor memiliki kapitalisasi pasar yang lebih besar daripada perusahaan target, maka akan memilih metode pembayaran kas demi keuntungan bersih yang lebih besar dibandingkan menggunakan metode pembayaran saham apabila sinergi tercapai. Menghitung kapitalisasi pasar dengan persamaan berikut.

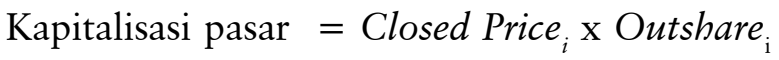

Keterangan:

Closed Price $_{i}=$ Harga pasar per lembar saham akuisitor i

Outshare $_{\mathrm{i}}=$ Jumlah saham beredar akuisitor $\mathrm{i}$

Hipotesis dirumuskan sebagai berikut.

H2.1: Semakin tinggi kapitalisasi pasar, maka akan semakin tinggi pula probabilitas akuisitor memilih metode pembayaran akuisisi dengan saham dibandingkan metode pembayaran akuisisi dengan kas.

H2.2: Semakin tinggi kapitalisasi pasar, maka akan semakin tinggi pula probabilitas akuisitor memilih metode pembayaran akuisisi dengan campuran dibandingkan metode pembayaran akuisisi dengan kas.

\section{Tobin's $\mathrm{Q}$}

Kinerja perusahaan dapat di-proxy-kan dengan menggunakan tobin's $Q$ untuk menilai bagaimana prospek pertumbuhan perusahaan di masa mendatang. Hasil dari penelitian yang dilakukan oleh Alshwer et al. (2011), Nini et al. (2009), dan Yang et al. (2017) menunjukkan 
bahwa akuisitor yang memiliki nilai Tobin's Q tinggi cenderung untuk memilih metode pembayaran akuisisi dengan saham dan campuran. Hal ini ditengarai adanya keinginan akuisitor untuk melakukan penghematan kas guna proyek yang menghasilkan net present value di masa mendatang. Menghitung tobin's $Q$ dengan persamaan berikut.

Tobin's $Q_{i}=\frac{\left(E M V_{i}+T D_{i}\right)}{B V T A_{i}}$

Keterangan:

$\mathrm{EMV}_{\mathrm{i}}=$ Equity Market Value akuisitor i

$\mathrm{TD}_{\mathrm{i}} \quad=$ Total Debt akuisitor i

BVTA $_{i}=$ Book value total aset akuisitor $\mathrm{i}$

Hipotesis dirumuskan sebagai berikut:

H3.1: Semakin tinggi tobin's $Q$, maka akan semakin tinggi pula probabilitas akuisitor memilih metode pembayaran akuisisi dengan saham dibandingkan metode pembayaran akuisisi dengan kas.

H3.2: Semakin tinggi tobin's $Q$, maka akan semakin tinggi pula probabilitas akuisitor memilih metode pembayaran akuisisi dengan campuran dibandingkan metode pembayaran akuisisi dengan kas.

\section{Cash Flow}

Kesehatan keuangan suatu perusahaan dapat dilihat bagaimana arus kasnya (cash flow). Akuisitor dengan cash flow yang besar cenderung untuk memilih metode pembayaran akuisisi dengan kas (Yang et al., 2017). Besarnya cash flow ini cenderung menguntungkan perusahaan untuk menggunakan metode pembayaran akuisisi dengan kas dibandingkan dengan metode pembayaran lainnya walaupun pada metode pembayaran kas terdapat pajak yang harus dibayarkan. Menghitung cash flow dengan persamaan berikut.

$\begin{array}{ll}\text { Cash flow } & =\frac{\text { Net } \text { Profit }_{i}+\text { Depreciation }_{i}}{T A_{\mathrm{i}}} \\ \text { Keterangan: } & \\ \text { NetProfit }_{i} & =\text { Laba bersih akuisitor i } \\ \text { Depreciation }_{i} & =\text { Depresiasi akuisitor } \mathrm{i} \\ \mathrm{TA}_{i} & =\text { Total aset akuisitor } \mathrm{i}\end{array}$

Hipotesis dirumuskan sebagai berikut.

H4.1: Semakin tinggi cash flow, maka akan semakin rendah pula probabilitas akuisitor memilih metode pembayaran akuisisi dengan saham dibandingkan metode pembayaran akuisisi dengan kas.

H4.2: Semakin tinggi cash flow, maka akan semakin rendah pula probabilitas akuisitor memilih metode pembayaran akuisisi dengan campuran dibandingkan metode pembayaran akuisisi dengan kas.

\section{Standar Deviasi Return Saham}

Risiko tidak sampainya suatu informasi ke pasar dan tingkat asimetri informasi diukur menggunakan standard deviasi return saham. Boone et al. (2014) dan Hasyim (2015) mengungkapkan hasil penelitian bahwa akuisitor yang memiliki standard deviasi return saham tinggi akan memilih metode pembayaran akuisisi dengan saham atau campuran. Menghitung standar deviasi return saham dengan persamaan berikut.

$\mathrm{SD}=\sqrt{\frac{\sum\left(\mathrm{r}_{\mathrm{i}}-\overline{\mathrm{r}}\right)^{2}}{\mathrm{n}-1}}$

Keterangan:

$\mathrm{r}_{\mathrm{i}}=$ Return saham akuisitor $\mathrm{i}$

$\overline{\mathrm{r}}=$ Return saham rata-rata

$\mathrm{n}-1=$ Jumlah sampel-1

Hipotesis dirumuskan sebagai berikut.

H5.1: Semakin tinggi standar deviasi return saham maka semakin rendah pula probabilitas akuisitor memilih metode pembayaran akuisisi dengan saham dibandingkan metode pembayaran akuisisi dengan kas. 
H5.2: Semakin tinggi standard deviasi return saham, maka akan semakin rendah pula probabilitas akuisitor memilih metode pembayaran akuisisi dengan campuran dibandingkan metode pembayaran akuisisi dengan kas.

\section{Korelasi Akuisitor}

Keputusan perusahaan dalam mengakuisisi perusahaan target apakah berada dalam korelasi bisnis yang sama dengan akuisitor ataukah tidak memiliki korelasi bisnis dengan akuisitor. Akuisitor apabila melakukan akuisisi dengan perusahaan target di industri yang sama dengan tujuan memperoleh economies of scale (Fluck dan Lynch, 1999) dan apabila mengakuisisi perusahaan target yang bukan berada di industri yang sama dengan tujuan memperoleh economies of scope.

\section{METODOLOGI DAN DATA \\ 1. Sampel}

Akuisitor yang sahamnya tercatat di Bursa Efek Indonesia (BEI) dan melakukan akuisisi dengan persentase $\geq 50 \%$ pada periode 2000 2017 adalah sampel dari penelitian ini dengan jumlah 85 transaksi akuisisi. Data transaksi diambil dari Thomson Reuters Eikon.

\section{Variabel}

\section{a. Variabel Dependen}

Variabel dependen pada penelitian ini adalah metode pembayaran akuisisi. Apabila akuisitor memilih metode pembayaran akuisisi dengan saham diberi kode 0, akuisitor memilih metode pembayaran akuisisi dengan campuran diberi kode 1, dan akuisitor memilih metode pembayaran akuisisi dengan kas diberi kode 2 .

\section{b. Variabel Independen}

Variabel independen yang digunakan adalah market to book ratio, kapitalisasi pasar, tobin's $Q$, cash flow, dan standard deviasi return saham akuisitor.

\section{c. Variabel Kontrol}

Variabel kontrol pada penelitian ini adalah korelasi akuisitor.

\section{Model Penelitian}

Model analisis yang digunakan pada penelitian ini adalah multinomial logit. Berikut model yang digunakan dalam penelitian: market capitalization, tobin's Q, cash flow, standard deviations of return, acquirer correlation.

a) Metode pembayaran akuisisi dengan saham:

$$
\begin{aligned}
\text { Saham }_{\mathrm{i}}= & \operatorname{Ln}(\mathrm{P}(\text { Saham }) / \mathrm{P}(\text { Kas })) \\
= & \beta 0+\beta 1 . \mathrm{MTB}_{\mathrm{i}}+\beta 2 . \text { MarCap }_{\mathrm{i}} \\
& +\beta 3 . \mathrm{Q}_{\mathrm{i}}+\beta 4 . \text { Cashflow }_{\mathrm{i}}+\beta 5 . \\
& \text { SDreturns }_{\mathrm{i}}+\beta 6 . \text { KorAc }_{\mathrm{i}}
\end{aligned}
$$

b) Metode pembayaran akuisisi dengan campuran:

$$
\begin{aligned}
\text { Campuran }_{\mathrm{i}}= & \operatorname{Ln}(\mathrm{P}(\text { Campuran }) / \mathrm{p}(\text { Kas })) \\
= & \beta 0+\beta 1 . \mathrm{MTB}_{\mathrm{i}}+\beta 2 . \text { MarCap }_{\mathrm{i}} \\
& +\beta 3 . \mathrm{Q}_{\mathrm{i}}+\beta 4 . \text { Cashflow }_{\mathrm{i}}+
\end{aligned}
$$$$
\beta 5 \text {. SDreturns } \mathrm{i}_{\mathrm{i}}+\beta 6 \text {. KorAc }_{\mathrm{i}}
$$

Keterangan:

Saham $_{\mathrm{i}} \quad$ : Variabel dependen metode pembayaran akuisisi dengan saham akuisitor $\mathrm{i}$

Campuran $_{\mathrm{i}}$ : Variabel dependen metode pembayaran akuisisi dengan campuran akuisitor i

$\beta_{\mathrm{n}} \quad:$ Koefisien regresi

MTB $_{\text {i }} \quad$ : Market to Book Ratio akuisitor i

$\operatorname{MarCap}_{\mathrm{i}} \quad$ : Kapitalisasi pasar akuisitor i

$\mathrm{Q}_{\mathrm{i}} \quad$ : Tobin's $\mathrm{Q}$ akuisitor $\mathrm{i}$

Cashflow- $_{i_{i}}:$ Cashflow akuisitor i

SDreturns $_{\mathrm{i}}$ : Risiko return saham akuisitor i

KorAc $_{\mathrm{i}}$ : Korelasi bisnis akuisitor $\mathrm{i}$ 


\section{HASIL PENELITIAN}

\section{Deskriptif Statistik}

Berdasarkan Tabel 1, market to book ratio memiliki nilai minimum 0,059568 , maksimum 69,1689, dan nilai rata-rata 3,8299. Hal ini mengindikasikan bahwa akuisitor memiliki saham yang overvalue. Kapitalisasi pasar memiliki nilai minimum 10,6808 , nilai maksimum 14,0974, dan nilai rata-rata 12,6294. Akuisitor di Indonesia memiliki kapitalisasi pasar yang cukup tinggi. Tobin's Q memiliki nilai minimum 0,0934, nilai maksimum 9,3198, dan nilai ratarata 1,4576 . Perusahaan yang melakukan akuisisi di Indonesia di indikasikan memiliki growth opportunity prospect yang rendah.

Variabel cash flow memiliki nilai minimum $-0,0474$, nilai maksimum 1,4976, dan nilai ratarata 0,2164 . Hal ini mengindikasikan bahwa akuisitor di Indonesia memiliki nilai arus kas yang cukup rendah. Standard deviasi return saham akuisitor memiliki nilai minimum 0 , nilai maksimum 1,6162, dan nilai rata-rata 0,0407. Return saham akuisitor memiliki nilai deviasi yang rendah.

Tabel 1 Deskriptif Statistik Variabel Penelitian

\begin{tabular}{|l|c|c|c|c|c|}
\hline & N & Min & Max & Mean & Std Dev \\
\hline MTB & 85 & 0,0596 & 69,1689 & 3,8299 & 10,0083 \\
MarCap & 85 & 10,6808 & 14,0974 & 12,6294 & 0,8338 \\
Q & 85 & 0,0934 & 9,3198 & 1,4576 & 1,4702 \\
CashFlow & 85 & $-0,0474$ & 1,4976 & 0,2164 & 0,2202 \\
SDreturn & 85 & 0 & 1,6162 & 0,0407 & 0,1758 \\
& & & & & \\
\hline
\end{tabular}

\section{Determinan Metode Pembayaran Akuisisi}

Hasil analisis regresi menyatakan bahwa semakin tinggi nilai market to book ratio, maka akan semakin tinggi probabilitas akuisitor memilih metode pembayaran akuisisi dengan saham dibandingkan metode pembayaran akuisisi dengan kas dan nilai odds ratio sebesar 1,727 .
Hasil ini juga sama dengan metode pembayaran akuisisi dengan campuran terkait market to book ratio yang tinggi akan membuat probabilitas akuisitor untuk pilihan metode pembayaran dengan nilai odds ratio sebesar 1,801. Probabilitas akuisitor memilih metode pembayaran akuisisi dengan campuran lebih tinggi dengan nilai odds ratio yang lebih tinggi daripada metode pembayaran akuisisi dengan saham.

Semakin tinggi nilai tobin's $Q$ akuisitor, maka akan semakin rendah probabilitas akuisitor untuk memilih metode pembayaran akuisisi dengan campuran dibandingkan metode pembayaran akuisisi dengan kas. Nilai odds ratio sebesar 0,226. Hasil ini menandakan bahwa akuisitor yang memiliki prospek pertumbuhan yang lebih baik di masa mendatang cenderung untuk memilih metode pembayaran akuisisi dengan kas. Hal ini dimungkinkan karena biaya akuisisi yang lebih murah daripada menggunakan metode pembayaran akuisisi dengan campuran ataupun saham.

Tabel 2 Analisis Regresi

\begin{tabular}{|c|c|c|c|c|}
\hline $\begin{array}{c}\text { Metode } \\
\text { Pembayaran }\end{array}$ & Variabel & B & Sig. & $\operatorname{Exp}(B)$ \\
\hline Saham & $\begin{array}{c}\text { MTB } \\
\text { MarCap } \\
\text { Q } \\
\text { CashFlow } \\
\text { SDreturn } \\
\text { KorAc } \\
\end{array}$ & $\begin{array}{c}0,546 \\
0,254 \\
-1,274 \\
-1,440 \\
-1,318 \\
-0,684 \\
\end{array}$ & $\begin{array}{c}0,075^{*} \\
0,643 \\
0,145 \\
0,512 \\
0,651 \\
0,476 \\
\end{array}$ & $\begin{array}{l}1,727 \\
1,289 \\
0,280 \\
0,237 \\
0,268 \\
0,504 \\
\end{array}$ \\
\hline Campuran & $\begin{array}{c}\text { MTB } \\
\text { MarCap } \\
\text { Q } \\
\text { CashFlow } \\
\text { SDreturn } \\
\text { KorAc }\end{array}$ & $\begin{array}{c}0,588 \\
0,569 \\
-1,486 \\
-0,979 \\
-10,417 \\
-1,248\end{array}$ & $\begin{array}{c}0,054^{*} \\
0,234 \\
0,085^{*} \\
0,570 \\
0,490 \\
0,105\end{array}$ & $\begin{array}{c}1,801 \\
1,766 \\
0,226 \\
0,376 \\
2,992 \mathrm{E}-005 \\
0,287\end{array}$ \\
\hline Pseudo $R^{2}$ & 0,211 & & & \\
\hline$C h i^{2}$ & 0,263 & & & \\
\hline
\end{tabular}

\section{E. KESIMPULAN}

Hasil penelitian ini mengonfirmasi hasil penelitian yang telah dilakukan oleh Bouwman et al. (2006) dan Yang et al. (2017). Di mana 
semakin tinggi market to book ratio, maka akan semakin tinggi probabilitas akuisitor memilih metode pembayaran akuisisi dengan saham atau campuran dibandingkan metode pembayaran akuisisi dengan kas. Semakin tinggi tobin's $Q$, maka semakin tinggi probabilitas akuisitor memilih metode pembayaran akuisisi dengan campuran dibandingkan metode pembayaran akuisisi dengan kas. Pada penelitian Hasyim (2015) menyatakan bahwa semakin tinggi standard deviasi return saham akuisitor, maka semakin rendah probabilitas akuisitor memilih metode pembayaran akuisisi dengan saham atau campuran dibandingkan metode pembayaran akuisisi dengan kas. Pada penelitian terbaru ini, standar deviasi return saham akuisitor tidak memengaruhi metode pembayaran akuisisi.

\section{F. DAFTAR RUJUKAN}

Alshwer, A.A., et al. 2011. Financial Constraints and the Method of Payment in Mergers and Acquisitions. SSRN.

Boone, Audra L., et al. 2014. Time Trend and Determinant of the Method of Payment in M\&As. Journal of Corporate Finance, 27, 296-304.

Bouwman, Christa H.S., et al. 2006. Market Valuation and Acquisition Quality: Empirical Evidence. Review of Financial Studies, Forthcoming.

Fluck, Z. \& A. Lynch. 1999. Why Firms Merge and then Divest: A Theory of Financial Synergy. Journal of Business, 72, 319-346 Hasyim, Valiant M.S. Nur. 2015. Determinan Metode Pembayaran Akuisisi di Indonesia: Periode 2000-2014. Skripsi. Fakultas Ekonomi dan Bisnis. Universitas Airlangga. Ismail, Ahmad dan Krause, Andre. 2010. Determinants of the Method of Payment in Mergers and Acquisitions. The Quarterly Review of Economics and Finance, 50, 471-484

Yang, Junhong, et al. 2017. To What Extent Does Corporate Liquidity Affect M\&A Decisions, Method of Payment and Performance? Evidence from China. Journal of Corporate Finance, XX, XXX-XXX. 